\title{
Bacterial vaginosis: a synthesis of the literature on etiology, prevalence, risk factors, and relationship with chlamydia and gonorrhea infections
}

Christian T. Bautista ${ }^{1 *}$, Eyako Wurapa ${ }^{2}$, Warren B. Sateren$^{2}$, Sara Morris ${ }^{1}$, Bruce Hollingsworth ${ }^{1}$ and Jose L. Sanchez ${ }^{3}$

\begin{abstract}
Bacterial vaginosis (BV) is a common vaginal disorder in women of reproductive age. Since the initial work of Leopoldo in 1953 and Gardner and Dukes in 1955, researchers have not been able to identify the causative etiologic agent of BV. There is increasing evidence, however, that BV occurs when Lactobacillus spp., the predominant species in healthy vaginal flora, are replaced by anaerobic bacteria, such as Gardenella vaginalis, Mobiluncus curtisii, M. mulieris, other anaerobic bacteria and/or Mycoplasma hominis. Worldwide, it estimated that 20-30\% of women of reproductive age attending sexually transmitted infection (STI) clinics suffer from BV, and that its prevalence can be as high as 50-60\% in high-risk populations (e.g., those who practice commercial sex work (CSW). Epidemiological data show that women are more likely to report BV if they: 1) have had a higher number of lifetime sexual partners; 2) are unmarried; 3) have engaged in their first intercourse at a younger age; 4) have engaged in CSW, and 5) practice regular douching. In the past decade, several studies have provided evidence on the contribution of sexual activity to BV. However, it is difficult to state that BV is a STI without being able to identify the etiologic agent. BV has also emerged as a public health problem due to its association with other STIS, including: human immunodeficiency virus (HIV), herpes simplex virus type 2 (HSV-2), Chlamydia trachomatis (CT) and Neisseria gonorrhoeae (NG). The most recent evidence on the association between BV and CT/NG infection comes from two secondary analyses of cohort data conducted among women attending STI clinics. Based on these studies, women with BV had a 1.8 and 1.9-fold increased risk for NG and CT infection, respectively. Taken together, BV is likely a risk factor or at least an important contributor to subsequent NG or CT infection in high-risk women. Additional research is required to determine whether this association is also present in other low-risk sexually active populations, such as among women in the US military. It is essential to conduct large scale cross-sectional or population-based case-control studies to investigate the role of BV as a risk factor for CT/NG infections. These studies could lead to the development of interventions aimed at reducing the burden associated with bacterial STIs worldwide.
\end{abstract}

Keywords: Bacterial vaginosis, Chlamydia, Gonorrhea, Military, Epidemiology, STI

\footnotetext{
* Correspondence: m.bautista@lancaster.ac.uk

'Division of Health Research, Lancaster University, Lancaster, UK

Full list of author information is available at the end of the article
} 


\section{Background}

Over the past two decades, several in vitro and in vivo studies have reported that bacterial vaginosis (BV), a common vaginal condition in women of reproductive age, is a biological risk factor associated with transmission of sexually transmitted infections (STIs), including chlamydia and gonorrhea infection. Although the aetiology of bacterial vaginosis is still unknown, it is believed that occurs when Lactobacillus spp., the predominant species in healthy vaginal flora, is replaced by anaerobes, mainly Gardnerella vaginalis. The purpose of this review is to provide information that clearly discusses on etiology and epidemiology of $\mathrm{BV}$, and especially its association with transmission of chlamydia and gonorrhea infections. For STI control efforts, the role of BV on these common bacterial infections is an important area for research because there is evidence from randomized trials that screening and treating of asymptomatic women with BV reduce the risk of infection.

\section{Bacterial vaginosis Etiology}

In 1892, Doderlein identified, by culturing vaginal secretions of healthy women, Lactobacillus spp., a gram-positive facultative anaerobic bacteria first discovered in sour milk by Scheele in 1780 and subsequently in humans by Folwarczny in 1858 [1]. In 1921, Schroeder confirmed Doderlein's findings and developed three grades to assess the microbial composition of the vaginal flora. These grades are as follows: 1) healthy vaginal microflora (grade I); 2) Lactobacillus spp. partially replaced by other bacteria (grade II), and 3) Lactobacillus spp. completely replaced by other bacteria (grade III) [2]. Seven years after Schroeder's work, Thomas identified Doderlein's bacteria by microscopy and culture as Lactobacillus acidophilus [3]. Based on these findings, Thomas and Schroeder suggested that vaginal discharge is associated with a lactobacilli-deficiency.

Until the mid-1950s, physicians used the term "nonspecific vaginitis" for women with lactobacillary grade III vaginal discharge without yeast cells or Trichomonas vaginalis [1]. In 1953, Leopold, a US Army captain, was the first to isolate and describe a small, gram-negative, nonmotile, nonencapsuled, rod-shaped bacterium from cervical swabs of women with cervicitis and from men with prostatitis. Although he did not name its species, he suggested that the organism was a member of the genus Haemophilus [4]. Two years later, Gardner and Dukes isolated the organism reported by Leopold in women with non-specific bacterial vaginitis, and based on its origin, the organism was named Haemophilus vaginalis. They were also the first to describe $H$. vaginalis as the causative agent of non-specific vaginal infections [5]. In 1978, Pheifer confirmed the findings of Leopold, Gardner and Dukes after treating women with non-specific vaginitis with metronidazole, an antimicrobial drug used to treat bacterial infections [6]. Since the first report of Gardner and Dukes in 1955, numerous researchers have identified $H$. vaginalis in women attending venereal disease clinics in the US [7, 8].

Questions have been raised about the identification of $H$. vaginalis as the etiologic agent of non-specific vaginitis since the initial publication by Gardner and Dukes [9]. In the first study by Gardner and Dukes, 2 out of 13 healthy women became infected after being inoculated with a pure culture of $H$. vaginalis. In their second study, 7 out of 29 women inoculated with $H$. vaginalis became infected. In their third study conducted with 15 healthy women who were inoculated intravaginally with $H$. vaginalis, 11 developed the infection. Combined, these experiments showed approximately $35 \%$ of inoculated women became infected with $H$. vaginalis. For Gardner and Dukes, the isolation of $H$. vaginalis in women inoculated with the bacteria was sufficient proof to postulate that $H$. vaginalis was the etiologic agent of non-specific vaginitis [10]. Nevertheless, most researchers rejected this finding of causality because it did not meet Koch's postulates, proposed in 1890, on the cause-andeffect relationship between bacteria and disease [11].

In the 1960s, there was considerable criticism on whether this small anaerobic bacterium belonged to the genus Haemophilus. In 1963, Zinnemann and Turner proposed renaming $H$. vaginalis as Corynebacterim vaginale because it has a corynebacterium-like morphology [12]. In 1979, Greenwood and Pickett indicated that $H$. vaginalis had no established genus, and thus, a new genus should be established for this bacterium [13]. Using several biochemical methods, such as DNA-DNA hybridization, biochemical analysis of the cell wall, and electron microscopy, in 1980, Greenwood and Pickett showed that $H$. vaginalis did not belong to the genus Haemophilus and renamed it Gardnerella vaginalis in honor of Gardner who had first reported the association between non-specific vaginitis and this bacteria [14]. In the same year, the name G. vaginalis was also supported by a second taxonomic study conducted by Piot [15]. Since 1983 physicians have used the term "bacterial vaginosis" to differentiate the vaginal discharge syndrome described by Gardner and Dukes from those caused by other microorganisms (e.g., parasites or fungi).

Other microorganisms in the vaginal microflora besides G. vaginalis have been discovered in the past two decades. These include Mobiluncus curtisii, M. mulieris, Mycoplasma hominis and anaerobic bacteria, such as Bacteroides spp., Prevotela spp., Peptostreptococcus spp., Fusobacterium spp., and Porphyromonas spp [1]. G. vaginalis has also been detected in culture samples from nearly all symptomatic women with bacterial vaginosis (BV) and in approximately $50 \%$ of the 
vaginal microflora of healthy women [16]. Reasons why other species of the genus Lactobacillus (e.g., $L$. gasseri, L. jensenii, L. iners, and L. crispatus), that also produce hydrogen peroxide (an antimicrobial product protecting against deleterious microorganisms), lactic acid (which maintains the normal vaginal $\mathrm{pH}$ balance between 3.5 and 4.5), and bacteriocins (homegrown antibiotics that inhibit the growth of harmful organisms within the vagina) are superseded by other pathogens (e.g., G. vaginalis) are unknown, as is their overall role in the vaginal microflora [17]. According to a conceptual model for BV pathogenesis developed by Schwebke in 2014, G. vaginalis is the pathogen responsible for the initiation of BV, with other pathogens acting as secondary "intruders" [18]. It is estimated that Lactobacillus spp. comprise 90-95\% of the total bacteria count in the healthy vaginal flora of reproductive age women and maintain balance in the vaginal ecosystem [19].

\section{Prevalence}

For clinicians, BV is a common vaginal condition characterized by at least three of the following four Amsel criteria: 1) thin, gray/white discharge; 2) malodorous "fishy" discharge upon adding $10 \%$ potassium hydroxide; 3) high vaginal $\mathrm{pH}(>4.5)$, and 4) identification of vaginal epithelial cells heavily coated with bacteria (i.e., "clue cells") [20]). For research purposes, BV is commonly diagnosed by a Gram's stain-based evaluation of vaginal bacterial morphotypes using the Nugent score ( $\geq 7$ indicates BV) [21]. It is assumed that BV is characterized by the replacement of normal vaginal lactobacilli with that of anaerobic microorganisms (e.g., G. vaginalis, Prevotella, Peptostreptococcus, and Bacteriodes spp). This replacement causes an imbalance in the vaginal microflora, which is the pathophysiologic process responsible for the discharge. It is estimated that $20-30 \%$ of women with vaginal discharge have $\mathrm{BV}$, although the prevalence can be as high as $50-60 \%$ in some high-risk sexual behavior populations $[16,22]$.

A 2013 systematic review reported that BV prevalence varies between and within countries worldwide [23]. Women from South and East Africa have higher rates of BV (68 \% in Mozambique, $51 \%$ in Lesotho, $44 \%$ in Kenya, 37 \% in Gambia) compared to women from West Africa (7 \% in Burkina Faso) [21]. In Norway (24 \%), Turkey (23\%), and Poland (19\%), women have moderately high BV rates. Women from Southeast Asia, Australia, New Zealand, and Indonesia have rates of BV that are typically greater than $30 \%$. Women in Latin America and the Caribbean have lower rates of BV, except in rural and antenatal populations in Jamaica and Peru (rates of $-40 \%$ ). In the US, BV is a common condition among women, with prevalence varying by race/ ethnicity: African-American (51\%), Hispanic (32\%), and whites (23\%). Similarly, in Canada, aboriginal and indigenous women have high BV rates (33 \%). Among female military recruits to the US Marine Corps between 1999 and 2000, the prevalence of BV was $27 \%$ [24]. According to this study, Native American (34 \%), African-American (32\%), and Hispanic (30 \%) female recruits had the highest BV burden. Data from the US Defense Medical Surveillance System indicates that between 2004 and 2013, 149,666 (15,000 cases per year) BV cases were reported in women in the US military. Of these, $45 \%$ occurred among U.S. Army personnel (unpublished data).

A recent ecological study conducted by Kenyon and Colebunders among males in 11 countries (Central African Republic, Brazil, Cote d'Ivoire, Kenya, Lesotho, Philippines, Singapore, Sri Lanka, Thailand, Zambia, and Tanzania) reported a moderate correlation between the number of partners (as measured by the question, "Do you now have one or more than one spouse/regular partner?") and BV prevalence $\left(R^{2}=0.57\right)$ [25]. Recent studies conducted among pregnant, HIV-positive and infertile women have also reported high BV prevalences. Among pregnant women in northeastern Nigeria and Ethiopia, the prevalence of BV was 17 and $19 \%$, respectively [26, 27]; among human immunodeficiency virus (HIV) positive women, a BV prevalence of $48 \%$ has been described in India [28], whereas among infertile women in Qom and Iran the prevalence of BV was found to be $70 \%$ [29]. Information on the burden of BV in Eastern Europe is limited. However, in Bulgaria, by polymerase chain reaction (PCR) and Gram's staining methods, the BV prevalence was found to be 56 and $57 \%$, respectively [30]. It has also been reported that the prevalence of $\mathrm{BV}$ is high among women with tubal factor infertility in Nigeria [31].

In recent years, BV among women who have sex with women (WSW) has received additional research attention. Between 1995 and 2014, five studies have reported high prevalence estimates ( 25 to $\sim 50 \%)$ among WSW [32]. Although there is no specific anatomic or physiologic reason to explain this high prevalence, it has been hypothesized that vaginal fluid exchange may represent an efficient mode of transmission, much as occurs with penile-vaginal sex. Researchers believe that WSW are also a unique high-risk population for the study of BV pathogenesis. Moreover, there is evidence that sexual relationships and behaviors have a strong influence on BV acquisition. These findings would support the hypothesis that BV is sexually transmitted.

\section{Epidemiology and risk factors}

Several studies have identified numerous sexual risk behaviors and other risk factors associated with BV [32-48]. Women are more likely to suffer from BV if they: 1) report 
a higher number of lifetime sexual partners: 2) are unmarried; 3) were at younger at their first intercourse; 4) self-identify as commercial sex workers (CSWs), and 5) practice regular douching. Other epidemiologic risk factors which have been implicated to a lesser degree include: 1) a high frequency of vaginal intercourse ("state frequency"); 2) a history of pregnancy, and 3) cigarette smoking [35]. In 2014, Jespers et al., reported that recent unprotected sex within 14 to $72 \mathrm{~h}$ prior to sampling was a risk factor for BV among CSWs in Kenya, Rwanda, and South Africa; unprotected sex was measured by the presence of prostate-specific antigen in the vaginal fluid [37]. This finding added to the literature the finding that in high-risk populations, male semen and vaginal penetration influence the development of BV. A recent systematic review and meta-analysis identified female genital mutilation or cutting as a risk factor for BV development [38]. In addition, a secondary data analysis of HIV-negative CSWs from South Africa, Uganda, Benin, and India showed that recent vaginal cleansing increases the risk of BV recurrence and that consistent condom use decreases the risk of BV [39]. To date, there is no clear evidence that BV is associated with pelvic inflammatory disease, although several studies have reported a link between BV and cervicitis [40].

A recent large cross-sectional study conducted among 53,652 rural married women in China reported that over 35 days of the menstrual cycle, less than 3 days of menstruation, dysmenorrhea, and usage of an intrauterine device were associated with BV [41]. Other studies have also reported that personal hygiene behaviors, such as vaginal douching, are consistently associated with BV [42]. On the other hand, current use of hormonal contraception, the luteal phase of menstrual cycle, a higher income, and vaginal candidiasis have been reported as protective factors for BV among women attending cervical screenings in south eastern Brazil [43]. Findings from a large cohort study conducted among CSWs in Uganda indicated that hormonal contraception was a protective factor against BV [44]. This finding has been corroborated in a recent systematic review and meta-analysis, where the authors found that hormonal contraception reduces the risk of $\mathrm{BV}$, and thus has a potential implication for prevention [45]. In addition to hormonal contraception, consistent condom use with a primary partner has been found to prevent the recurrence BV among CSWs, highlighting the importance of this barrier method [46]. Although several studies have found numerous protective and risk factors associated with BV in different risk behavior groups, data on the emotional, sexual and social impact of living with $\mathrm{BV}$ is sparse in the literature. A recent study conducted by Bilardi et al. [47] reported that women with recurrent BV felt embarrassed, 'dirty', ashamed and worried that others may detect their malodor and abnormal discharge. Therefore, BV affected their self-esteem and sex lives by making them avoid having sexual contact with their partners.

There is additional evidence that oral and anal sex may increase the risk of BV. Among adolescent girls who visited sexually transmitted infection (STI) clinics in Baltimore, Maryland, between 1990 and 2002, BV was reported more often among those who reported oral and anal sex [48]. In another study, receptive anal sex before vaginal sex was independently associated with $B V$ among 773 young sexually active women $18-30$ years of age [49]. In high-risk groups such as WSW, it was found that the use of vaginal sex toys, oral-anal sex (e.g., anilingus), presence of a BV condition in the female partner and a higher lifetime number of female sex partners increased the risk of BV [50]. A recent study conducted in 355 lesbian and bisexual women using a computerassisted self-interview approach revealed that presence of Lactobacillus gasseri and vaginal lubricant use increased the risk for BV [51]. In a second study among 196 African American WSW, douching within the past 30 days, younger age (18 years or less) at first sexual encounter with a female partner, and two or more male lifetime sexual partners were positively associated with BV [52]. Data from a 24-month WSW cohort study involving visits every 3 months found that receptive oral sex, BV symptom onset, and exposure to a new sexual partner positively influenced BV acquisition. This same study reported that women who co-enrolled with a BV-negative partner reduced their risk of BV acquisition by $74 \%$ [32].

Despite 60 years of research since the work of Leopold, Gardner and Dukes in the 1950s, the causative or etiologic agent(s) of BV has not been definitively established. Therefore, it is difficult to state that BV constitutes a STI or condition, although there is growing evidence supporting the hypothesis that BV is sexually transmitted [53]. As an example, in the past decade, numerous studies have reported the contribution of sexual activity to BV, and BV has further emerged as a global issue of concern due to its association with STIs [54]. Fig. 1 shows the timeline of the main milestones of BV and its association with STIs. A 2009 systematic review and meta-analysis on sexual risk factors associated with BV noted that the epidemiological profile of BV is similar to common bacterial STIs, such as chlamydia and gonorrhea. This would support the hypothesis that BV is sexually transmitted and that the number of sexual partners and condom use are risk and protective factors for BV, respectively. For some researchers there is a possibility that sexual activity may be a risk indicator for BV transmission. For instance, Verstraelen stated that BV constitutes a sexually enhanced disease, is not a classic STI and that BV transmission increases with the frequency of sexual intercourse [35]. Verstraelen also agreed with Vallor [55] and Leppaluoto [56], both of whom 


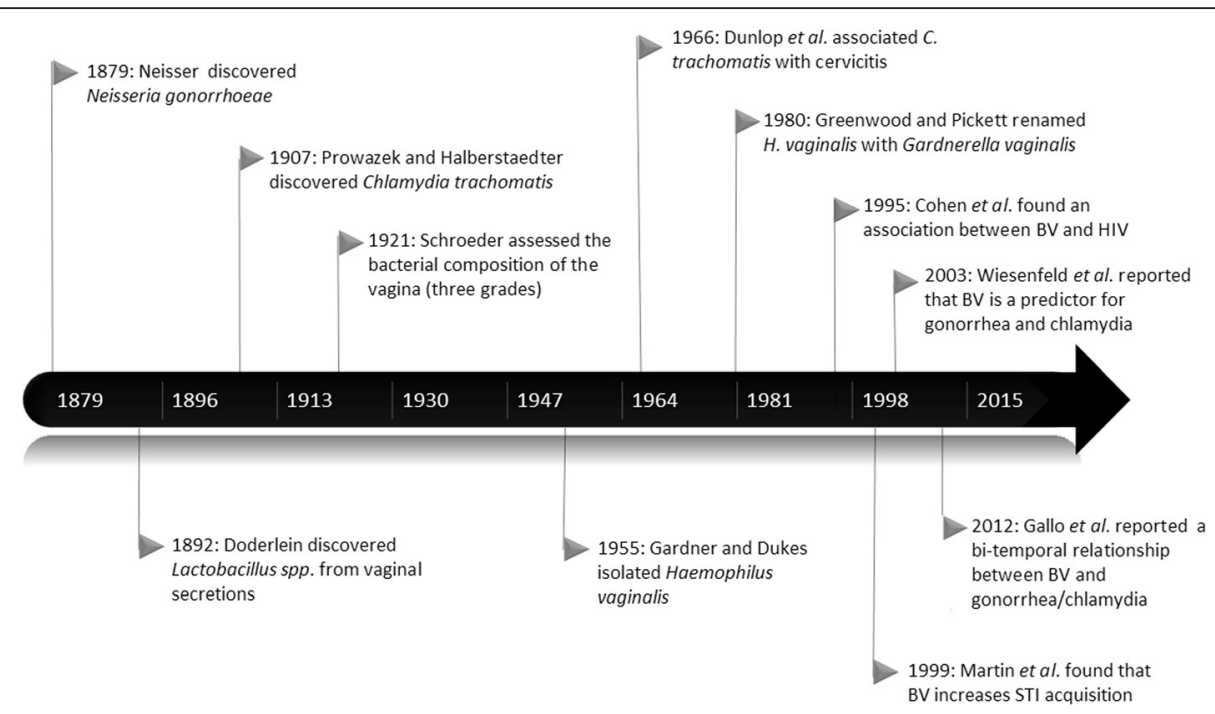

Fig. 1 Timeline and milestones related to bacterial vaginosis and associated sexually transmitted pathogens; 1879 to present. Note: BV, bacterial vaginosis; H. vaginalis, Haemophilus vaginalis; STI, sexually transmitted infections; HIV, human immunodeficiency virus; C. trachomatis, Chlamydia trachomatis

reported that an increasing frequency of sexual intercourse is associated with an imbalance of the vaginal microflora in favor of BV-related microorganisms. In contrast, Marrazzo suggests that there is evidence to support a role for acquisition of BV, but this process may vary among subsets of women [57]. Elevated cervicovaginal levels of interleukin (IL)-1 beta, IL-6, and IL-8, which are higher in pregnant adolescents with BV, may increase one's vulnerability to a STI [58].

\section{Chlamydia and gonorrhea}

Genital Chlamydia trachomatis (CT) is a common bacterial STI worldwide that is spread through oral, anal, or vaginal sex in both women and men [59]. Based on US National Health and Nutrition Examination Survey (NHANES) data collected from 2007 to 2012, the prevalence of chlamydia has been estimated to be $1.7 \%$ among adults 14-39 years old [60]. Data from NHANES also indicates that African-Americans (5.2\%), people with two or more lifetime sexual partners (3.2\%), divorced/widowed/separated participants (3.0\%), and participants 20-24 years of age (2.9\%) have higher infection rates. In the US, it is estimated that 2.8 million cases of chlamydia are reported each year [61]. According to the Armed Forces Health Surveillance Center (AFHSC), from 2000 to 2012, the human papillomavirus (HPV, 304,021 cases), chlamydia (198,274 cases), and gonorrhea $(41,713$ cases) were the three most frequently diagnosed STIs among US military personnel on active duty status [62].

One epidemiologic characteristic of a Chlamydia infection is that it is usually asymptomatic ( $75 \%$ in women, $\sim 50 \%$ in men) [63]. In women, common chlamydia symptoms include abdominal pain, abnormal vaginal discharge, intermenstrual bleeding, painful intercourse, burning while urinating, vaginal bleeding after intercourse, and a yellow discharge with a strong odor [64]. In men, the most common chlamydia symptom is urethritis, followed by a burning sensation during urination, and itching of the skin of the penis. Younger age is the main risk factor associated with chlamydia among women, and $60-70 \%$ of chlamydia infections are reported among adolescents and young adults $<25$ years of age [59]. Other risk factors associated with infection are: 1) smoking; 2) substance use; 3) preceding HPV infection; 4) number of lifetime sexual partners; 5) sex with new partners; 6) lack of condom use, and 7) having a sex partner with a CT infection, cervicitis, and/or prior history of chlamydia or other STI $[65,66]$. In women, chlamydia causes cervicitis, urethritis, and endometritis. Untreated cervicitis can cause pelvic inflammatory disease (PID), ectopic pregnancy, infertility, and chronic pelvic pain. In men, untreated chlamydia may cause tender or swollen testicles and a decline in sperm mobility and concentration, which are both associated with infertility [66].

Neisseria gonorrhoeae (NG) is a bacterium that causes gonorrhea, a curable and very contagious infection transmitted through genital and anal sex and less frequently through oral sex [67]. It constitutes the second most common STI worldwide accounting for $\sim 100$ million of the estimated $\sim 500$ million new cases of curable STIs worldwide annually [68]. In the US, approximately one million cases were reported at the disease's peak in 1975 , with decreasing incidence to 350,000 cases by the year 2000. The principal factor in gonorrhea's decline was the widespread use of penicillin as a first line 
antimicrobial in the mid-1970s [69]. In 2013, the national incidence of gonorrhea was 106.1 cases per 100,000 persons. Of the 333,004 cases reported that year, $93 \%$ occurred in persons aged 15-44 years. Gonorrhea is also commonly reported among active duty personnel in the US Armed Forces, with stable incidence rates since 2001 ( 200 cases per 100,000 persons-years) [62].

In men, gonorrhea most commonly presents as acute urethritis. Asymptomatic infection rates may be as high as $75 \%$, in much the same manner as chlamydia infections are for women. In women, the bacteria initially infect the endocervical canal causing gonococcal cervicitis; however, gonorrhea is asymptomatic in up to 70$90 \%$ of women, providing an important reservoir of infection [70]. When symptomatic, common signs and symptoms in women are vaginal discharge (green or yellow color) with an unpleasant odor, together with bleeding during sexual intercourse, painful urination, or itching.

For both men and women, the strongest risk factor associated with a NG infection is young age (15-24 years) [71]. Other risk factors/indicators include: 1) AfricanAmerican or Hispanic race/ethnicity; 2) illicit drug use; 3) casual sex partners; 4) presence of other STI pathogens (e.g., chlamydia); 5) history of STIs; 6) lack of barrier contraception, and 7) inconsistent condom use [72, 73]. Biological, behavioral, and socio-cultural factors influence the risk of gonorrhea transmission in adolescents and young adult populations [74-76]. First, compared to older women, younger women have larger areas of cervical ectropion and thus are biologically more susceptible to infection. Second, sexually active younger populations engage in more risky sexual behaviors (e.g., multiple sexual partners) compared to the general population, increasing the risk of infection. Finally, at the community level, a gender imbalance represents a factor for transmission; in areas with more women than men, young women are vulnerable to subtle coercion to engage in high-risk sexual behaviors.

In the past decade, a new generation of non-culture tests called nucleic acid amplification tests (NAATs), which are both highly sensitive and specific, have revolutionized diagnosis of gonorrhea and chlamydia infections [77]. Two valuable characteristics of NAAT 'testing' are the use of less invasive samples, including self-collected specimens such as urine samples, and the possibility of detecting both gonorrhea and chlamydia using the same specimen [78].

\section{Bacterial vaginosis and associations with HIV, chlamydia, and gonorrhea}

In 1995, Cohen reported a positive relationship between BV and HIV in CSWs from Chiang Mai, Thailand [79]. Since then, this association has been reported in pregnant and postnatal women in Malawi, women in South Africa, and CSWs in Kenyan, among others [80-82]. A systematic review of 23 cohort studies estimated that BV increases the risk of HIV by $60 \%$ [83]. Although

Table 1 Summary of studies evaluating the association of bacterial vaginosis with Chlamydia trachomatis and Neisseria gonorrhoeae

\begin{tabular}{|c|c|c|c|c|}
\hline Reference & Location & Study design & Population & Findings \\
\hline $\begin{array}{l}\text { Joesoef, } \\
\text { et al. [85] }\end{array}$ & Indonesia & Cross-sectional & Pregnant women & $\begin{array}{l}\text { Women with BV had more than a 2-fold increase in } \\
\text { chlamydia and a } 6 \text {-fold increase in gonorrhea }\end{array}$ \\
\hline $\begin{array}{l}\text { Keane, et al. } \\
{[86]}\end{array}$ & London, UK & Case-control & $\begin{array}{l}\text { Women attending genitourinary } \\
\text { medicine clinics }\end{array}$ & Association between chlamydia and BV (odds ratio $=5.4$ ) \\
\hline $\begin{array}{l}\text { Nilsson, } \\
\text { et al. [87] }\end{array}$ & Stockholm, Sweden & Cross-sectional & $\begin{array}{l}\text { Women attending family planning } \\
\text { and youth clinics }\end{array}$ & $\begin{array}{l}\text { BV is associated with sexual behavior risk factors similar } \\
\text { to those associated with Chlamydia }\end{array}$ \\
\hline $\begin{array}{l}\text { Martin, et al. } \\
\text { [88] }\end{array}$ & Mobasa, Kenya & Cohort & Sex workers & $\begin{array}{l}\text { Absence of vaginal lactobacilli increased the risk of } \\
\text { gonorrhea (hazard ratio }=1.7 \text { ) }\end{array}$ \\
\hline $\begin{array}{l}\text { Wiesenfeld, } \\
\text { et al. [89] }\end{array}$ & Pennsylvania, US & Cross-sectional & $\begin{array}{l}\text { Non-pregnant women who } \\
\text { sought care at STD clinics }\end{array}$ & $\begin{array}{l}\text { Women with BV were more likely to test positive } \\
\text { for } N . \text { gonorrhoeae (odds ratio }=-4.1 \text { or C. trachomatis } \\
(\mathrm{OR}=3.4)\end{array}$ \\
\hline $\begin{array}{l}\text { Ness, et al. } \\
{[90]}\end{array}$ & $\begin{array}{l}\text { Pennsylvania, Colorado, } \\
\text { California, Alabama, } \\
\text { South Carolina, US }\end{array}$ & Cohort & $\begin{array}{l}\text { Women visiting planning clinics, } \\
\text { university health clinics, gynecology } \\
\text { clinics, and STD units }\end{array}$ & $\begin{array}{l}\text { Baseline BV prevalence was associated with gonococcal } \\
\text { or chlamydial genital infection }(\mathrm{OR}=2.8)\end{array}$ \\
\hline $\begin{array}{l}\text { Allsworth, } \\
\text { et al. [91] }\end{array}$ & Rhode Island, US & Cohort & $\begin{array}{l}\text { Women attending primary care, } \\
\text { gynecology, and family planning } \\
\text { clinics }\end{array}$ & $\begin{array}{l}\text { Severity of BV (Nugent score }>8 \text { ) was associated with } \\
\text { the incident of a STI (C. trachomatis, N. gonorrhoeae, } \\
\text { Trichomonas vaginalis, or pelvic inflammatory disease) }\end{array}$ \\
\hline $\begin{array}{l}\text { Brotman, } \\
\text { et al. [92] }\end{array}$ & Alabama, US & Cohort & $\begin{array}{l}\text { Non-pregnant women visiting } \\
\text { clinics for routine care }\end{array}$ & $\begin{array}{l}\mathrm{BV} \text { at the prior visit increased the risk of a subsequent } \mathrm{C} \text {. } \\
\text { trachomatis (hazard ratio }=1.9 \text { ) and } \mathrm{N} \text {. gonorrhoeae } \\
\text { (hazard ratio }=1.8 \text { ) infection }\end{array}$ \\
\hline $\begin{array}{l}\text { Gallo, et al. } \\
\text { [93] }\end{array}$ & Alabama, US & Cohort & $\begin{array}{l}\text { Women attending public } \\
\text { STD clinics }\end{array}$ & $\begin{array}{l}\text { BV increased the risk of gonorrhea/chlamydia (pairwise } \\
\text { odds ratio }=1.6 \text { ) and gonorrhea/chlamydia also increased } \\
\text { the risk of BV (pairwise odds ratio }=2.4 \text { ) }\end{array}$ \\
\hline
\end{tabular}


causality remains unclear, a high $\mathrm{pH}$ in the vaginal environment ( $>4.5$ ) may allow for the adherence and survival of HIV, increasing the risk of HIV infection. Other studies also indicate that BV is a risk for both ulcerative (e.g., herpes simplex virus type 2 [HSV-2], syphilis [84] and non-ulcerative STIs (e.g., gonorrhea, chlamydia).

The relevant epidemiological studies published on BV, CT, NG and HIV are shown in Table 1. Joesoef in 1996 was the first to report an association of BV with chlamydia (two-fold increase) and gonorrhea (six-fold increase) among pregnant women with BV in Indonesia and suggested BV as a potential marker for these two common bacterial STIs [85]. One year later, Keane conducted a casecontrol study among 51 couples and observed a strong association between chlamydia and BV (odds ratio $=5.4$ ) [86]. That same year, a large Swedish cross-sectional study involving 1101 women found that high-risk sexual behaviors, such as a high number of lifetime sexual partners, a history of anal sex, having multiple partners in the last month, and a history of sexual abuse and rape were similar among both BV and chlamydia patients [87]. In 1999, Martin found that absence of vaginal lactobacilli increased the risk of gonorrhea (hazard ratio $=1.7$ ), but not chlamydia [88]. Wiesenfeld reported a strong relationship between BV and both CT and NG infections following exposure to male partners with urethritis; this study was conducted among 255 non-pregnant women 15-30 years of age [89]. In this study, women with BV were 4.1 times more likely to test positive for NG and 3.4 times more likely to test positive for CT compared to women without BV. Among 1179 African-American women who were followed for 3 years with visits every 6 and 12 months between 1999 and 2001, Ness et al., found that BV was associated with concurrent NG and CT infections at baseline but not subsequently [90]. However, the authors conducted a trial of NG/CT treatment during follow-up and this might have affected their estimates. According to a secondary data analysis of 535 women at high-risk for STI, Allsoworth observed that BV severity, as measured by a high Nugent score (8-10), was associated with incident STIs (NG, CT and Trichomonas vaginalis) and with severe BV cases experiencing a 2-fold increased risk for STIs compared to women with normal vaginal flora [91].

Findings from two cohort studies associating BV with a CT or NG infection were published in 2010 and 2012 $[92,93]$. Both studies were conducted among nonpregnant women. According to Brotman's study, which was a secondary analysis of 3620 non-pregnant women 15-44 years of age enrolled in the Longitudinal Study of Vaginal Flora in Birmingham, Alabama from 1999 to 2002, women with BV (measured as a Nugent score of 7-10) had a 1.8- and 1.9-fold increased risk for gonorrhea and chlamydia, respectively. The second cohort study conducted by Gallo re-analyzed data from a large condom intervention study among 1159 women who attended public STI clinics between 1995 and 1998 in Birmingham and Huntsville, Alabama, and used generalized estimating equations methods to account for multiple individual visits (6 monthly follow-up visits). The authors reported that women with an incident BV episode at a prior visit were at a 1.6 times the risk of having chlamydia or gonorrhea at a subsequent follow-up visit. In addition, Gallo found a relationship between these two bacterial STIs and BV; namely, chlamydia or gonorrhea increased by 2.4 times the risk of having BV at a subsequent visit. This represents the first report of a temporal relationship working in both directions between BV and chlamydia/ gonorrhea. Recently, two studies have reported a significant association between BV and these STIs among women in Durban, South Africa and among female sex workers in Uganda [58, 94].

Considered together, multiple studies report BV as a risk factor or at least an important contributor in subsequent gonorrhea or chlamydia infection. It is important to note that the observation that BV increases the risk of chlamydia or gonorrhea was mainly seen in high-risk women (e.g., CSWs, women attending STI clinics, and/or women at risk for unplanned pregnancies). Additionally, the two recent cohort publications are based on secondary data analyses of data collected in the late 1990s to early 2000s, and their findings must be interpreted with caution considering the changes in the epidemiology of chlamydia in the US over the past decade. We believe that additional research with increased sample sizes and using modern epidemiological and statistical methods in other young sexually active women affected by these bacterial STIs are warranted. For instance, women serving in the US Armed Forces can provide additional data-based evidence about the role of $\mathrm{BV}$ as a risk factor or indicator for CT and NG infection. In addition, molecular studies to determine risk factors and adverse outcomes associated with the subtypes of BV in different risk behaviors groups are also required. Data from these studies may provide additional evidence as to the epidemiology of this leading disorder among women of reproductive age.

\section{Prevention implications}

Although a definitive causative agent for BV has not yet been shown, there is evidence, albeit among higher risk groups, that the presence of BV is positively associated with both CT and NG occurrence. Existing findings to date suggest that patients, clinicians and public health personnel should be made aware of the positive association of BV with CT and NG, and given the clustering of risk behaviors behind both, should pay additional attention to education on sexual hygiene measures (i.e., douching as a risk factor for BV) and sexual risk behaviors for both BV and CT/NG (i.e., younger age at sexual intercourse, higher number of 
sexual partners, sex with partner with STI history, and most importantly the lack of barrier contraception). A clinician diagnosis of $\mathrm{BV}$ can be a risk alert for eventual patient acquisition of STIs and counseling is suggested, with elevated concern for women presenting with repeat BV infections. Despite the potential for prevention measures associated with the identification of $\mathrm{BV}$ as a risk indicator for common STIs, there is still the need for further research among young women not in high risk sexual behavior groups. Notwithstanding the need for additional research information, data to date suggest a role for BV diagnosis, treatment and prevention in STI prevention.

\section{Conclusion}

Since the discovery by Leopold in 1953 of the microorganism associated with non-specific vaginitis, now named Gardnerella vaginalis, there has been increasing evidence that the replacement of vaginal lactobacilli with this microorganism is associated with BV and that it is the most common cause of abnormal vaginal discharge among women of reproductive age. Although the epidemiological profile of BV seems to be similar to chlamydia and gonorrhea, this cannot be interpreted as evidence that BV is an STI. In the past decade, numerous studies have reported an association between BV and STI pathogens, such as HIV, HSV-2, CT, and NG. The biological mechanisms underlying such an association are still unknown; however, there is growing evidence supporting the hypothesis that BV increases the risk of acquiring STIs. Studies relating BV to chlamydia or gonorrhea were conducted mainly among nonrepresentative high-risk populations; thus, additional research is required to determine whether these associations are also present in other young sexually active populations (e.g., among women in the US military). The effect of BV on chlamydia or gonorrhea is an interesting area for future research because there is evidence from two randomized trials that screening and treating asymptomatic women with BV reduces the risk of acquiring a CT or NG infection. Twice-weekly prophylactic use of intravaginal metronidazole gel significantly reduced the incidence of CT infections among women attending a STI clinic in Alabama [95], and the incidence of CT and NG infections was lower among US and African women who used intravaginal metronidazole/miconzaole compared to the placebo group [96]. Therefore, to determine the role of BV as a risk factor for $\mathrm{CT} / \mathrm{NG}$ infections, it is essential to conduct large studies to provide solid epidemiological evidence in favor of such associations.

\section{Ethical approvals}

This study protocol was reviewed and approved by institutional review boards at Lancaster University and Walter Reed Army Institute of Research.

\section{Abbreviations}

AFHSC: Armed Forces Health Surveillance Center; BV: bacterial vaginosis; CSW: commercial sex worker; CT: chlamydia trachomatis; DNA: deoxyribonucleic acid; HIV: human immunodeficiency virus; HSV-2: herpes simplex virus type 2; NAAT: nucleic acid amplification test; NG: neisseria gonorrhoeae; NHANES: National Health and Nutrition Examination Survey; PCR: polymerase chain reaction; PID: pelvic inflammatory disease; STI: sexually transmitted infection; US: United States; WSW: women who have sex with women.

\section{Competing interests}

The authors declare that they have no competing interests.

\section{Authors' contributions}

CB drafted the manuscript. WS, EW, SM, BH, and JLS conceptualized the review and gave valuable comments and suggestions. All authors read and approved the final manuscript.

\section{Authors' information}

Christian T. Bautista, MS, MPH, Lancaster University, Lancaster, United Kingdom, LA1 4YG.

\section{Acknowledgments}

The authors thank Sebastian-Santiago for technical assistance.

\section{Disclaimer}

The views expressed herein are those of the authors and do not reflect the official policy or position of the Department of the Army, Department of Defense, the US Government, or any organization listed. Some authors are employees of the US government. This work was prepared as part of their official duties and, as such, there is no copyright to be transferred.

\section{Funding}

This study was funded by the US Armed Forces Health Surveillance Center and its Division of Global Emerging Infectious Surveillance and Response (AFHSC-GEIS).

\section{Author details}

${ }^{1}$ Division of Health Research, Lancaster University, Lancaster, UK. ${ }^{2}$ Walter Reed Army Institute of Research, Maryland, USA. ${ }^{3}$ Armed Forces Health Surveillance Center and Cherokee Nation Technology Solutions, Maryland, USA.

Received: 16 September 2015 Accepted: 28 January 2016

Published online: 13 February 2016

\section{References}

1. Donders GG. Definition and classification of abnormal vaginal flora. Best Pract Res Clin Obstet Gynaecol. 2007:2:355-73.

2. Donders GG, Vereecken A, Salembier G, Van Bulck B, Spitz B. Assessment of vaginal lactobacillary flora in wet mount and fresh or delayed gram's stain. Infect Dis Obstet Gynecol. 1996;4:2-6.

3. Thomas S. Doderlein's bacillus: Lactobacillus acidophilus. J Infect Dis. 1928 ; 43:218-27.

4. Leopold S. Heretofore undescribed organism isolated from the genitourinary system. US Armed Forces Med. 1953;4:263-6.

5. Gardner HL, Dukes CD. Haemophilus vaginalis vaginitis: a newly defined specific infection previously classified non-specific vaginitis. Am J Obstet Gynecol. 1955;69:962-76.

6. Pheifer TA, Forsyth PS, Durfee MA, Pollock HM, Holmes KK. Nonspecific vaginitis: role of Haemophilus vaginalis and treatment with metronidazole. N Engl J Med. 1978;298:1429-34.

7. Holst E, Wathne B, Hovelius B, Mardh PA. Bacterial vaginosis: microbiological and clinical findings. Eur J Clin Microbiol. 1987;6:536-41.

8. Martius J, Krohn MA, Hillier SL, Stamm WE, Holmes KK, Eschenbach DA. Relationships of vaginal Lactobacillus species, cervical Chlamydia trachomatis, and bacterial vaginosis to preterm birth. Obstet Gynecol. 1988;71:89-95.

9. van der Meijden WI. Clinical aspects of Gardnerella vaginalis-associated vaginitis. A review of the literature. Scand J Urol Nephrol Suppl. 1984;86:135-41.

10. Spiegel CA. Bacterial vaginosis. Clin Microbiol Rev. 1991;4:485-502.

11. Ren X. Toward a more systematic understanding of bacterial virulence factors and establishing Koch postulates in silico. Virulence. 2013;4:437-8. 
12. Zinnemann $\mathrm{K}$, Turnerg C. The taxonomic position of 'Haemophilus vaginalis' (Corynebacterium vaginale). J Pathol Bacteriol. 1963;21:3-219.

13. Greenwood JR, Pickett MJ. Salient features of Haemophilus vaginalis. J Clin Microbiol. 1979;9:200-4.

14. Greenwood JR, Pickett MJ. Transfer of Haemophilus vaginalis Gardner and Dukes to a new genus, Gardnerella: G. vaginalis (Gardner and Dukes). Int J Syst Bacteriol. 1980;30:170-8.

15. Piot $P$, van Dyck E, Goodfellow M, Falkow S. A taxonomic study of Gardnerella vaginalis (Haemophilus vaginalis) Gardner and Dukes 1955. J Gen Appl Microbiol. 1980;119:373-96.

16. Livengood CH. Bacterial vaginosis: an overview for 2009. Rev Obstet Gynecol. 2009;2:28-37.

17. Antonio MA, Hawes SE, Hillier SL. The identification of vaginal Lactobacillus species and the demographic and microbiologic characteristics of women colonized by these species. J Infect Dis. 1999;180:1950-6.

18. Schwebke JR, Muzny CA, Josey WE. Role of Gardnerella vaginalis in the pathogenesis of bacterial vaginosis: a conceptual model. J Infect Dis. 2014; 210:338-43.

19. Martin $\mathrm{DH}$. The microbiota of the vagina and its influence on women's health and disease. Am J Med Sci. 2012;343:2-9.

20. Amsel R, Totten PA, Spiegel CA, Chen KC, Eschenbach D, Holmes KK. Nonspecific Vaginitis. Diagnostic criteria and microbial and epidemiologic associations. Am J Med. 1983;74:14-22.

21. Nugent RP, Krohn MA, Hillier SL. Reliability of diagnosing bacterial vaginosis is improved by a standardized method of gram stain interpretation. J Clin Microbiol. 1991;29:297-301.

22. Rubins A. Bacterial Vaginosis. In: Gross G, Tyring SK, editors. Transmitted Infections and Sexually Transmitted Diseases Sexually. Berlin: Springer; 2011. p. 203-6. doi:10.1007/978-3-642-14663-3_19.

23. Kenyon C, Colebunders R, Crucitti T. The global epidemiology of bacterial vaginosis: a systematic review. Am J Obstet Gynecol. 2013;209:505-23.

24. Yen S, Shafer MA, Moncada J, Campbell CJ, Flinn SD, Boyer CB. Bacterial vaginosis in sexually experienced and non-sexually experienced young women entering the military. Obstet Gynecol. 2003;102:927-33.

25. Kenyon CR, Colebunders R. Strong association between the prevalence of bacterial vaginosis and male point-concurrency. Eur J Obstet Gynecol Reprod Biol. 2014;172:93-6.

26. Ibrahim SM, Bukar M, Galadima GB, Audu BM, Ibrahim HA. Prevalence of bacterial vaginosis in pregnant women in Maiduguri. North-Eastern Nigeria Niger J Clin Pract. 2014;17:154-8.

27. Mengistie Z, Woldeamanuel Y, Asrat D, Adera A. Prevalence of bacterial vaginosis among pregnant women attending antenatal care in Tikur Anbessa University Hospital, Addis Ababa, Ethiopia. BMC Res Notes. 2014;7:822.

28. Lallar M, Nanda S, Nandal R. Lower Genital Tract Infections in HIV-Infected Women: Can We Afford to Miss? J Obstet Gynaecol India. 2015;65:45-9.

29. Ghiasi M, Fazaeli H, Kalhor N, Sheykh-Hasan M, Tabatabaei-Qomi R. Assessing the prevalence of bacterial vaginosis among infertile women of Qom city. Iran J Microbiol. 2014;6:404-8.

30. Gergova RT, Strateva TV, Mitov IG. Gardnerella vaginalis-associated bacterial vaginosis in Bulgarian women. Braz J Infect Dis. 2013;17:313-8.

31. Durugbo II, Nyengidiki TK, Bassey G, Wariso KT. Bacterial vaginosis among women with tubal factor infertility in Nigeria. Int J Gynaecol Obstet. 2015;131:133-6.

32. Vodstrcil LA, Walker SM, Hocking JS, Law M, Forcey DS, Fehler G, et al. Incident bacterial vaginosis (BV) in women who have sex with women is associated with behaviors that suggest sexual transmission of BV. Clin Infect Dis. 2015;60:1042-53.

33. Ness RB, Hillier SL, Richter HE, Soper DE, Stamm C, McGregor J, et al. Douching in relation to bacterial vaginosis, lactobacilli, and facultative bacteria in the vagina. Obstet Gynecol. 2002;100:765.

34. Smart $S$, Singal A, Mindel A. Social and sexual risk factors for bacterial vaginosis. Sex Transm Infect. 2004;80:58-62.

35. Schwebke JR, Desmond R. Risk factors for bacterial vaginosis in women at high risk for sexually transmitted diseases. Sex Transm Dis. 2005;32:654-8.

36. Verstraelen $H$, Verhelst $R$, Vaneechoutte $M$, Temmerman $M$. The epidemiology of bacterial vaginosis in relation to sexual behaviour. BMC Infect Dis. 2010;10:81.

37. Jespers V, Crucitti T, Menten J, Verhelst R, Mwaura M, Mandaliya K, et al. Prevalence and correlates of bacterial vaginosis in different sub-populations of women in sub-saharan africa: A cross-sectional study. PLoS One. 2014;9, e109670.

38. Berg RC, Underland V, Odgaard-Jensen J, Fretheim A, Vist GE. Effects of female genital cutting on physical health outcomes: a systematic review and meta-analysis. BMJ Open. 2014;4, e006316.
39. Guédou FA, Van Damme L, Deese J, Crucitti T, Becker M, Mirembe F, et al. Behavioural and medical predictors of bacterial vaginosis recurrence among female sex workers: longitudinal analysis from a randomized controlled trial. BMC Infect Dis. 2013;13:208. doi:10.1186/1471-2334-13-208.

40. Taylor BD, Darville T, Haggerty CL. Does bacterial vaginosis cause pelvic inflammatory disease? Sex Transm Dis. 2013;40:117-22.

41. Li XD, Wang CC, Zhang XJ, Gao GP, Tong F, Li X, et al. Risk factors for bacterial vaginosis: results from a cross-sectional study having a sample of 53,652 women. Eur J Clin Microbiol Infect Dis. 2014;33:1525-32.

42. Klebanoff MA, Nansel TR, Brotman RM, Zhang J, Yu KF, Schwebke JR, et al. Personal hygienic behaviors and bacterial vaginosis. Sex Transm Dis. 2010;37:94-9.

43. Marconi C, Duarte MT, Silva DC, Silva MG. Prevalence of and risk factors for bacterial vaginosis among women of reproductive age attending cervical screening in southeastern Brazil. Int J Gynaecol Obstet. 2015:131:137-41.

44. Francis SC, Looker C, Vandepitte J, Bukenya J, Mayanja Y, Nakubulwa S, et al. Bacterial vaginosis among women at high risk for HIV in Uganda: high rate of recurrent diagnosis despite treatment. Sex Transm Infect. 2015. doi:10.1136/sextrans-2015-052160.

45. Vodstrcil LA, Hocking JS, Law M, Walker S, Tabrizi SN, Fairley CK, et al. Hormonal contraception is associated with a reduced risk of bacterial vaginosis: a systematic review and meta-analysis. PLoS One. 2013;8, e73055.

46. Guédou FA, Van Damme L, Deese J, Crucitti T, Becker M, Mirembe F, et al. Behavioural and medical predictors of bacterial vaginosis recurrence among female sex workers: longitudinal analysis from a randomized controlled trial. BMC Infect Dis. 2013;13:208.

47. Bilardi JE, Walker S, Temple-Smith M, McNair R, Mooney-Somers J, Bellhouse C, et al. The burden of bacterial vaginosis: women's experience of the physical, emotional, sexual and social impact of living with recurrent bacterial vaginosis. PLoS One. 2013;8, e74378.

48. Brotman RM, Erbelding EJ, Jamshidi RM, Klebanoff MA, Zenilman JM, Ghanem KG. Findings associated with recurrence of bacterial vaginosis among adolescents attending sexually transmitted diseases clinics. Pediatr Adolesc Gynecol. 2007:20:225-31.

49. Cherpes TL, Hillier SL, Meyn LA, Busch JL, Krohn MA. A delicate balance: risk factors for acquisition of bacterial vaginosis include sexual activity, absence of hydrogen peroxide-producing lactobacilli, black race, and positive herpes simplex virus type 2 serology. Sex Transm Dis. 2008;35:78-83.

50. Marrazzo JM, Koutsky LA, Eschenbach DA, Agnew K, Stine K, Hillier SL. Characterization of vaginal flora and bacterial vaginosis in women who have sex with women. J Infect Dis. 2002;185:1307-13.

51. Marrazzo JM, Thomas KK, Agnew K, Ringwood K. Prevalence and risks for bacterial vaginosis in women who have sex with women. Sex Transm Dis. 2010;37:335-9.

52. Muzny CA, Austin EL, Harbison HS, Hook 3rd EW. Sexual partnership characteristics of African American women who have sex with women; impact on sexually transmitted infection risk. Sex Transm Dis. 2014;41:611-7.

53. Koumans EH, Kendrick JS. CDC Bacterial vaginosis Working Group:Preventing adverse sequelae of bacterial vaginosis: a public health program and research agenda. Sex Transm Dis. 2001;28:292-7.

54. Fethers KA, Fairley CK, Morton A, Hocking JS, Hopkins C, Kennedy L, et al. Early sexual experiences and risk factors for bacterial vaginosis. J Infect Dis. 2009:200:1662-70.

55. Vallor AC, Antonio MA, Hawes SE, Hillier SL. Factors associated with acquisition of, or persistent colonization by vaginal lactobacilli: role of hydrogen peroxide production. J Infect Dis. 2001;184:1431-6.

56. Leppaluoto PA. Autopsy of bacterial vaginosis: a physiological entity rather than a contagious disease. Acta Obtet Gynecol Scand. 2008;87:578-9.

57. Marrazzo JM. Interpreting the epidemiology and natural history of bacterial vaginosis: are we still confused? Anaerobe. 2011;17:186-90.

58. Ferreira CS, Marconi C, Parada CM, Duarte MT, Gonçalves AP, Rudge MV et al. Bacterial vaginosis in pregnant adolescents: proinflammatory cytokine and bacterial sialidase profile. Cross-sectional study. Sao Paulo Med J. 2015; 133(6):465-70. doi:10.1590/1516-3180.2014.9182710.

59. Vasilevsky S, Greub G, Nardelli-Haefliger D, Baud D. Genital Chlamydia trachomatis: understanding the roles of innate and adaptive immunity in vaccine research. Clin Microbiol Rev. 2014;27:346-70.

60. Torrone E, Papp J, Weinstock H. Centers for Disease Control and Prevention (CDC). Prevalence of chlamydia trachomatis genital infection among persons aged 14-39 years-United States, 2007-2012. MMWR Morb Mortal Wkly Rep. 2014;63:834-8 
61. Satterwhite CL, Torrone E, Meites E, Dunne EF, Mahajan R, Ocfemia MC, et al. Sexually transmitted infections among US women and men: prevalence and incidence estimates, 2008. Sex Transm Dis. 2013;40:187-93.

62. Armed Forces Health Surveillance Center. Sexually transmitted infections, active component, U.S. Armed Forces, 2000-2012. MSMR. 2013;20:5-10.

63. Dielissen PW, Teunissen DA, Lagro-Janssen AL. Chlamydia prevalence in the general population: is there a sex difference? a systematic review. BMC Infect Dis. 2013;13:534

64. Mishori R, McClaskey EL, WinklerPrins VJ. Chlamydia trachomatis infections: screening, diagnosis, and management. Am Fam Physician. 2012:86:1127-32.

65. Bébéar C, de Barbeyrac B. Genital Chlamydia trachomatis infections. Clin Microbiol Infect. 2009;15:4-10.

66. Gimenes F, Souza RP, Bento JC, Teixeira JJ, Maria-Engler SS, Bonini MG, et al. Male infertility: a public health issue caused by sexually transmitted pathogens. Nat Rev Urol. 2014;11:672-87.

67. Holmes KK, Bell TA, Berger RE. Epidemiology of sexually transmitted diseases. Urol Clin North Am. 1984;11:3-13.

68. World Health Organization. Global action plan to control the spread and impact of antimicrobial resistance in Neisseria gonorrhoeae. Geneva: WHO Press; 2012

69. Romanowski B, Sutherland R, Anand CM. Epidemic of gonorrhea due to penicillinase-producing Neisseria gonorrhoeae. Can Med Assoc J. 1982;127: 1201-3.

70. Walker CK, Sweet RL. Gonorrhea infection in women: prevalence, effects, screening, and management. Int J Womens Health. 2011;3:197-206.

71. Manhart LE, Aral SO, Holmes KK, Critchlow CW, Hughes JP, Whittington WL, et al. Influence of study population on the identification of risk factors for sexually transmitted diseases using a case-control design: the example of gonorrhea. Am J Epidemiol. 2004;160:393-402.

72. Peipert JF, Lapane KL, Allsworth JE, Redding CA, Blume JL, Lozowski F, et al. Women at risk for sexually transmitted diseases: correlates of intercourse without barrier contraception. Am J Obstet Gynecol. 2007;197:1-8.

73. Loza O, Strathdee SA, Martinez GA, Lozada R, Ojeda VD, Staines-Orozco H, et al. Risk factors associated with chlamydia and gonorrhoea infection among female sex workers in two Mexico-USA border cities. Int J STD AIDS. 2010;21:460-5.

74. Casey PM, Long ME, Marnach ML. Abnormal cervical appearance: what to do, when to worry? Mayo Clin Proc. 2011;86:147-50.

75. Panchaud C, Singh S, Feivelson D, Darroch JE. Sexually transmitted diseases among adolescents in developed countries. Fam Plann Perspect. 2000;32:24-32

76. Baumeister RF, Vohs KD. Sexual economics: sex as female resource for social exchange in heterosexual interactions. Pers Soc Psychol Rev. 2004;8:339-63.

77. Johnson RE, Newhall WJ, Papp JR, Knapp JS, Black CM, Gift TL, et al. Screening tests to detect Chlamydia trachomatis and Neisseria gonorrhoeae infections-2002. MMWR Recomm Rep. 2002;51:1-38.

78. Tabrizi SN, Unemo M, Limnios AE, Hogan TR, Hjelmevoll SO, Garland SM, et al. Evaluation of six commercial nucleic acid amplification tests for detection of Neisseria gonorrhoeae and other Neisseria species. J Clin Microbiol. 2011;49:3610-5.

79. Cohen CR, Duerr A, Pruithithada N, Rugpao S, Hillier S, Garcia P, et al. Bacterial vaginosis and HIV seroprevalence among female commercial sex workers in Chiang Mai, Thailand. AIDS. 1995;9:1093-7.

80. Taha TE, Hoover DR, Dallabetta GA, Kumwenda NI, Mtimavalye LA, Yang LP, et al. Bacterial vaginosis and disturbances of vaginal flora: association with increased acquisition of HIV. AIDS. 1998;12:1699-706.

81. Sewankambo N, Gray RH, Wawer MJ, Paxton L, McNaim D, Wabwire-Mangen F, et al. HIV-1 infection associated with abnormal vaginal flora morphology and bacterial vaginosis. Lancet. 1997;350:546-550.

82. Myer L, Denny L, Telerant R, Souza M, Wright Jr TC, Kuhn L. Bacterial vaginosis and susceptibility to HIV infection in South African women: a nested case-control study. J Infect Dis. 2005;192:1372-80.

83. Atashili J, Poole C, Ndumbe PM, Adimora AA, Smith JS. Bacterial vaginosis and HIV acquisition: a meta-analysis of published studies. AIDS. 2008;22(12):1493-501.

84. Esber A, Vicetti Miguel RD, Cherpes TL, Klebanoff MA, Gallo MF, Turner AN. Risk of Bacterial Vaginosis Among Women With Herpes Simplex Virus Type 2 Infection: A Systematic Review and Meta-analysis. J Infect Dis. 2015;212:8-17.

85. Joesoef MR, Wiknjosastro G, Norojono W, Sumampouw H, Linnan M, Hansell $\mathrm{MJ}$, et al. Coinfection with chlamydia and gonorrhoea among pregnant women and bacterial vaginosis. Int J STD AIDS. 1996;7:61-4.

86. Keane FE, Thomas BJ, Whitaker L, Renton A, Taylor-Robinson D. An association between non-gonococcal urethritis and bacterial vaginosis and the implications for patients and their sexual partners. Genitourin Med. 1997;73:373-7.
87. Nilsson U, Hellberg D, Shoubnikova M, Nilsson S, Mårdh PA. Sexual behavior risk factors associated with bacterial vaginosis and Chlamydia trachomatis infection. Sex Transm Dis. 1997;24:241-6.

88. Martin HL, Richardson BA, Nyange PM, Lavreys L, Hillier SL, Chohan B, et al. Vaginal lactobacilli, microbial flora, and risk of human immunodeficiency virus type 1 and sexually transmitted disease acquisition. J Infect Dis. 1999; 180:1863-8.

89. Wiesenfeld HC, Hillier SL, Krohn MA, Landers DV, Sweet RL. Bacterial vaginosis is a strong predictor of Neisseria gonorrhoeae and Chlamydia trachomatis infection. Clin Infect Dis. 2003;36:663-8.

90. Ness RB, Kip KE, Soper DE, Hillier S, Stamm CA, Sweet RL, et al. Bacterial vaginosis (BV) and the risk of incident gonococcal or chlamydial genital infection in a predominantly black population. Sex Transm Dis. 2005;32:413-7.

91. Allsworth JE, Peipert JF. Severity of bacterial vaginosis and the risk of sexually transmitted infection. Am J Obstet Gynecol. 2011;205:e1-6.

92. Brotman RM, Klebanoff MA, Nansel TR, Yu KF, Andrews WW, Zhang J, et al. Bacterial vaginosis assessed by gram stain and diminished colonization resistance to incident gonococcal, chlamydial, and trichomonal genital infection. J Infect Dis. 2010;202:1907-15.

93. Gallo MF, Macaluso M, Warner L, Fleenor ME, Hook 3rd EW, Brill I, et al. Bacterial vaginosis, gonorrhea, and chlamydial infection among women attending a sexually transmitted disease clinic: a longitudinal analysis of possible causal links. Ann Epidemiol. 2012;22:213-20.

94. Abbai NS, Reddy T, Ramjee G. Prevalent bacterial vaginosis infection - a risk factor for incident sexually transmitted infections in women in Durban, South Africa. Int J STD AIDS. 2015. doi:10.1177/0956462415616038.

95. Schwebke JR, Desmond R. A randomized trial of metronidazole in asymptomatic bacterial vaginosis to prevent the acquisition of sexually transmitted diseases. Am J Obstet Gynecol. 2007;196:517. e1-6.

96. Balkus J, Anzala O, Kimani J, Schwebkre J, Lee J, Kabare E, et al. Periodic presumptive treatment for vaginal infections may reduce chlamydia and gonorrhea incidence: a secondary analysis from the Preventing Vaginal Infections Trial. Brisbane: World STI and HIV Congress; 2015.

\section{Submit your next manuscript to BioMed Central and we will help you at every step:}

- We accept pre-submission inquiries

- Our selector tool helps you to find the most relevant journal

- We provide round the clock customer support

- Convenient online submission

- Thorough peer review

- Inclusion in PubMed and all major indexing services

- Maximum visibility for your research

Submit your manuscript at www.biomedcentral.com/submit
(O) BioMed Central 